\title{
Geotechnical Properties of Rubber Tires and Sediments Mixtures
}

\author{
Hamid Sellaf \\ Civil Engineering \\ Department, Djillali \\ Liabes University of Sidi \\ Bel Abbes, Algeria \\ hamidsellaf@yahoo.com
}

\author{
Habib Trouzine \\ Civil Engineering \\ Department, Djillali \\ Liabes University of Sidi \\ Bel Abbes, Algeria \\ h_trouzine@yahoo.fr
}

\author{
Mouloud Hamhami \\ Civil Engineering \\ Department, Djillali \\ Liabes University of Sidi \\ Bel Abbes, Algeria \\ mouloudhm@yahoo.fr
}

\author{
Aissa Asroun \\ Civil Engineering \\ Department, Djillali \\ Liabes University of Sidi \\ Bel Abbes, Algeria \\ a_asroun@yahoo.fr
}

\begin{abstract}
An experimental work was undertaken to study the effect of rubber tires on the geotechnical properties of a dredged sediment, using a mixing ratio of large size. For comparison, two types of soil were studied (dredged sediment from Fergoug dam and Tizi Tuff from the north west of Algeria). Taking into account the high compressibility and the low water absorption of the rubber tires, grain size analysis, density, Atterberg limits analysis, chemical composition, direct shear tests, loadingunloading tests, modified Proctor and CBR tests are performed on the two soils and their mixtures with different scrap tire rubber (10, 20, 25 and $50 \%)$. The results show that liquid limits and plastic indexes decrease with the scrap tire rubber content and that the decrease is more significant for soil with high plasticity. Cohesion also decreases with scrap tire rubber content when the internal friction angle is vacillating. Compression and recompression indexes increase gradually with the scrap tire rubber content and the variation for compression index is more significant for the two soils. Compaction characteristics and CBR values decrease with scrap tire rubber content. The CBR values for $W=3 \%$ are important compared to those with $W=5 \%$ excepted for mixture with (75\% tuff and $25 \%$ scrap tire rubber). The results show that the scrap tire rubber can be used as a reinforcement material for dredged soil, but with a content that should not highly affect the compressibility.
\end{abstract}

Keywords—-sediments; waste tires; rubber; valorizing; tests; geotechnical

\section{INTRODUCTION}

The world's reservoirs are currently filling up with sediments at a rate of approximately $1 \%$ per year [1, 2]. This implies that within about 50 years, the world's water storage in reservoirs will be half of the current storage, which will have large economical and environmental consequences, especially in semi-arid environments where many reservoirs have been built for water supply, irrigation, flood control and production of electricity [3]. Fergoug dam is one of many others that have such problems. It is located in the North-West of Algeria, at the bottom of the Atlas buttresses, approximately $20 \mathrm{~km}$ in the south of the town of El-Mohammadia (province of Mascara) (Figure 1). The total catchment area of Fergoug is estimated to be $8340 \mathrm{~km}^{2}$. The average altitude is about $790 \mathrm{~m}$ with a maximum altitude of $1454 \mathrm{~m}$ [4].

In its actual position the Fergoug dam is an earthfill dam with an initial capacity of 17 million $\mathrm{m}^{3}$ in 1970. In 1977, its capacity fell to 9.67 million $\mathrm{m}^{3}$, with an annual rate of silting exceeding one million of $\mathrm{m}^{3}$ [4]. Several methods of valorization are available such as the sediments dredging reuse. These methods understand valorization with physics, chemical, biological, immobilization, thermal additives [5-13].

Pneumatic waste is polluting and cumbersome. It constitutes a varied population by size, degrees of ageing, wear, shapes of ears. The worn tires are composed primarily of synthetic rubber, carbon dioxide, silicon and steel. Algeria generates over than 26000 tons of waste tires per year [14]. Waste tires can be disposed in landfills or tire stockpiles. There are several methods of recycling tires in the field of civil engineering e.g. as a retaining wall and as a decorative element [15-16].

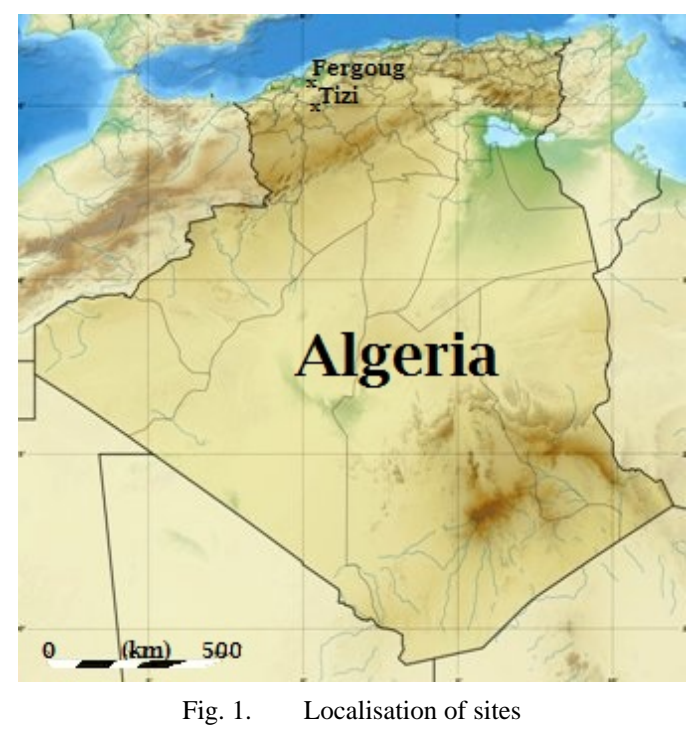


Currently several researchers directed their studies on the valorization of the sediments, with the aim of using them in the field of civil engineering, which portrays the greatest need for materials. This work is interested particularly in the valorization of the sediments, with an aim of studying the mechanical behavior of the scrap rubber mixtures compared to other results of Tizi Tuff which is primarily used in the area of Mascara with the same percentage of scrap rubber.

\section{EXPERIMENTAL STUDY}

\section{A. Materials and methods}

\section{1) Investigated soils}

Two soils of different origins and physical properties were selected. The first sample was obtained from a site located in Fergoug in Mascara in the north-west of Algeria. The second sample was a Tuff from the region of Tizi, Mascara in the north-west of Algeria. These two soils were subject to several laboratory identification tests using standard procedures adopted by AFNOR and ISO standards [17-21]. The results are shown in Table I. The specific weight of the Fergoug sample was $24.6 \mathrm{kN} / \mathrm{m}^{3}$ while that of the Tuff was $25.9 \mathrm{kN} / \mathrm{m}^{3}$. The particle size distribution for the soils is shown in Table I. The chemical analysis of the soils was carried out in accordance with [22], and the results are presented in Table II.

\section{2) Tires rubber fibres}

Scrap tire rubber fibres can be obtained from tires through two principal processes: (i) ambient, which is a method of processing where scrap tire rubber is processed at or above ordinary room temperature; (ii) cryogenic, a process that uses liquid nitrogen to freeze the rubber until it becomes brittle and then uses a hammer mill to shatter the frozen rubber into smooth particles [23]. Tire rubber fibre consists of a complex mixture of elastomers, polyisoprene, polybutadiene and styrene-butadiene. Stearic acid (1.2\%), zinc oxide (1.9\%), extender oil (1.9\%) and carbon black (31.0\%), are also important components of tires [24-25].

TABLE I. SOME PROPERTIES OF THE INVESTIGATED SOILS

\begin{tabular}{|c|c|c|}
\hline Properties & Fergoug Sediment & Tizi Tuff \\
\hline Liquid limit (\%) & 38.28 & 28 \\
\hline Plastic limit (\%) & 15.09 & 13 \\
\hline Plasticity index (\%) & 23.19 & 15 \\
\hline Specific weight $\gamma_{s}\left(\mathrm{kN} / \mathrm{m}^{3}\right)$ & 24.6 & 25.9 \\
\hline Grains sizes analysis & - & - \\
\hline Gravel (\%) & 16 & 40 \\
\hline Sand (\%) & 28.6 & 50 \\
\hline Silt (\%) & 55.4 & 10 \\
\hline Clay (\%) & 4.5 \\
\hline Methylene blue values & 5.5 & 94.5 \\
\hline Volume of blue VB $\left(\mathrm{cm}^{3}\right)$ & 115.5 & \\
\hline Specific surface SST $\left(\mathrm{m}^{2} / \mathrm{g}\right)$ &
\end{tabular}

The used rubber fibre, the same used in [16], is produced from used automobile tires by shredding them mechanically in ambient temperature. Steel was removed by magnetic separation and textile by density. It was not possible to determine the gradation curve for the tire chips as for normal aggregates since they were elongated particles between 5 and $30 \mathrm{~mm}$ with an average value of $7 \mathrm{~mm}$ : the sample contains scrap tire rubber fibre (approximately 59\% of weight) and scrap tire rubber powder (approximately $41 \%$ of weight) with the latter tending to lump together. Scrap tire rubber was characterized by a specific weight of 0.83 and insignificant water absorption. Some behavior parameters of the rubber are given in Table III.

TABLE II. CHEMICAL COMPOSITIONS OF SOILS USED IN THE STUDY

\begin{tabular}{|c|c|c|}
\hline Property & Fergoug Sediment & Tizi Tuff \\
\hline $\mathrm{SiO}_{2}(\%)$ & 62.68 & 24.42 \\
\hline $\mathrm{Al}_{2} \mathrm{O}_{3}(\%)$ & 7.39 & 2.65 \\
\hline $\mathrm{Fe}_{2} \mathrm{O}_{3}(\%)$ & 0.71 & 0.58 \\
\hline $\mathrm{CaO}(\%)$ & 12.51 & 31.48 \\
\hline $\mathrm{MgO}(\%)$ & 0.37 & 2.61 \\
\hline $\mathrm{NaOH}(\%)$ & - & 4.90 \\
\hline $\mathrm{Cl}(\%)$ & - & - \\
\hline $\mathrm{P.F}_{2}(\%)$ & 16.27 & 33.39 \\
\hline
\end{tabular}

TABLE III. SOME PROPERTIES OF SCRAP TIRE RUBBER FIBRE

\begin{tabular}{|c|c|c|}
\hline Properties & Tire rubber fiber & References \\
\hline Density $\left(\mathbf{M g} / \boldsymbol{m}^{\mathbf{3}}\right)$ & $1.153-1.198$ & Akbulut et al. 2007 \\
\hline Tensile strength $(\mathbf{M P a})$ & $16-20$ & Khorami et al. 2010 \\
\hline Elongation (\%) & $400-500$ & Khorami et al. 2010 \\
\hline
\end{tabular}

\section{B. Mixtures design}

\section{1) Preparation of soil-rubber mixtures}

Because the temperature can alter the rubber, the water content of samples was determined by drying at $35^{\circ} \mathrm{C} \pm 5^{\circ} \mathrm{C}$. Samples were considered as completely dry when the difference between two weighings does not exceed $0.2 \%$ for an interval of 24 hours. According to some pertinent studies on fibre reinforced soils, the studied percentages of polypropylene are generally $0.05,0.015$ and $0.025 \%$ of the weight of the parent soil [26-27] or $0.1,0.2,0.3,0.4$ and $0.5 \%$ of the weight of the parent soil [28]. For tire rubber fibre, the studied percentages are 1, 2, 3, 4 and $5 \%$ of the total weight of the reinforced samples [28]. Fibres and lime or cement with soils were mixed in all of cited studies. Cetin et al. [29] studied mixtures prepared by cohesive soil with 10, 20, 25 and 50\% of pure fine and coarse grained tire-chips. For this study, soils were mixed with scrap tire rubber fibre and the contents of fibre were chosen as 10, 20, 25 and $50 \%$ by total weight of composite samples. As the fibre tended to lump together, considerable care and time were spent to get a homogeneous distribution of the fibre in the mixtures. The used materials were called S, T and C for Fergoug Sediment, Tizi Tuff and Scrap tire rubber fibre respectively.

\section{2) Preparation of composite soil samples}

In many researches, specimens are prepared at optimum proctor or at water content corresponding to the liquid limit. In our study, since the specific weight of rubber is less than half that of soils and used mix ratios are larger (till 50\% of scrap tire rubber), the sediment mixtures were prepared with $20 \%$ of water content and then specimens were statically compacted in the standard Proctor mould in five layers to ensure uniform dry density. Samples heave were allowed under a seating surcharge of $1 \mathrm{kPa}$, the choice of this seating surcharge is a result of the great difference of specific gravities of components. After the compaction of the soils and their mixtures, the cylindrical 
unreinforced and composite samples were extruded from the mould using a hydraulic jack. The samples were wrapped in plastic to prevent water loss.

Since it is impossible to determine the specific gravities of scrap tire rubber and composite samples with the method described in [18] (because rubber floats on the surface of the liquid), the specific weight of scrap tire rubber is measured by helium pycnometer while those of composite samples are calculated theoretically using each components' dry mass and specific gravities values as follow:

$\mathrm{G}_{\mathrm{s}}=\left(\mathrm{M}_{\mathrm{d} 1}+\mathrm{M}_{\mathrm{d} 2}\right) /\left[\left(\mathrm{M}_{\mathrm{d} 1} / \mathrm{G}_{\mathrm{s} 1}\right)+\left(\mathrm{M}_{\mathrm{d} 2} / \mathrm{G}_{\mathrm{s} 2}\right)\right]$

where:

$G_{s}:$ Specific density (dimensionless)

$M_{d}$ : Dry mass of specimen $(\mathrm{kg})$

Table IV presents the different specific gravities of the soils and their mixtures. It can be observed that the value of the specific weight of composite samples decreases with rubber content and reaches its half for the sample with $50 \%$ of scrap tire rubber content.

TABLE IV. SPECIFIC WEIGHT OF SOILS, SCRAP TIRE RUBBER AND THEIR MIXTURES.

\begin{tabular}{|c|c|c|c|c|c|c|c|}
\hline Rubber content & $\mathbf{0 \%}$ & $\mathbf{1 0} \%$ & $\mathbf{2 0 \%}$ & $\mathbf{2 5 \%}$ & $\mathbf{5 0 \%}$ & $\mathbf{1 0 0 \%}$ \\
\hline & \multicolumn{6}{|c|}{ Specific weight $\boldsymbol{\gamma}_{\boldsymbol{s}}\left(\mathbf{k} \mathbf{N} / \mathbf{m}^{3}\right)$} \\
\hline Sediment & $24.6^{\mathrm{a}}$ & $23.0^{\mathrm{b}}$ & $21.3^{\mathrm{b}}$ & $20.5^{\mathrm{b}}$ & $1.6 .4^{\mathrm{b}}$ & \multirow{2}{*}{$8.3^{\mathrm{a}}$} \\
\hline Tuff & $25.9^{\mathrm{a}}$ & $24.1^{\mathrm{b}}$ & $22.4^{\mathrm{b}}$ & $21.5^{\mathrm{b}}$ & $17.1^{\mathrm{b}}$ & \\
\hline
\end{tabular}

${ }^{\mathrm{a}}$ Experimental value, ${ }^{\mathrm{b}}$ Calculated value

\section{EXPERIMENTAL RESULTS AND DISCUSSION}

\section{A. Consistency limits}

Atterberg limit tests were performed to determine the consistency limits values of the soils and their mixtures according to the methods described in the French standard [17].

1) Effects of scrap tire rubber on the liquid limit

Figures 2 and 3 show the effects of fibre on the consistency limits for $\mathrm{S}$ and $\mathrm{T}$ soils and their mixtures. The liquid limits are expected to decrease gradually when the scrap tire rubber fibre content increases for the two soils. However, the reduction of the liquid limit for the $\mathrm{S}$ soil was considerable.

\section{2) Effects of scrap tire rubber on the plastic limit}

For the S soil, the plastic limit decreases gradually for the sample of increased fibre. For the $\mathrm{T}$ soil, the plastic limit decreases gradually for the sample of increased fibre. The results of Atterberg limit test indicate that the $\mathrm{S}$ soil has a higher value of plasticity index than the Tizi Tuff. The low plasticity of the $\mathrm{T}$ soil makes the mixtures less susceptible to fibre compared to the S soil.

The change in consistency limits of mixtures may be due to the mixture type [30], the cation exchange capacity [31-32], and the relative amount of clay mineral in the mixtures [33]. Interestingly, the plastic limits studied for tire-cohesive clayey soil mixtures by [29] stay at first about the same then show some amount of decrease and then stay about the same. These results are similar to those of typical fine grained cohesive soils with medium plasticity [29].

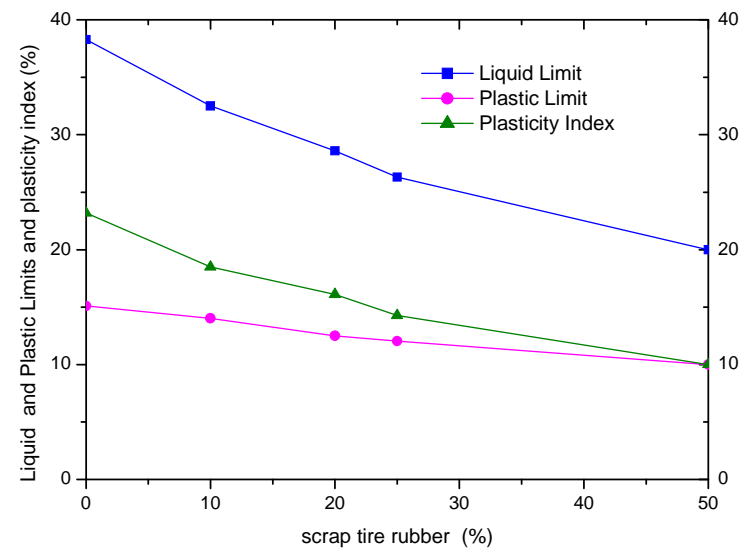

Fig. 2. Effect of rubber tires on the consistency limits of the soil S

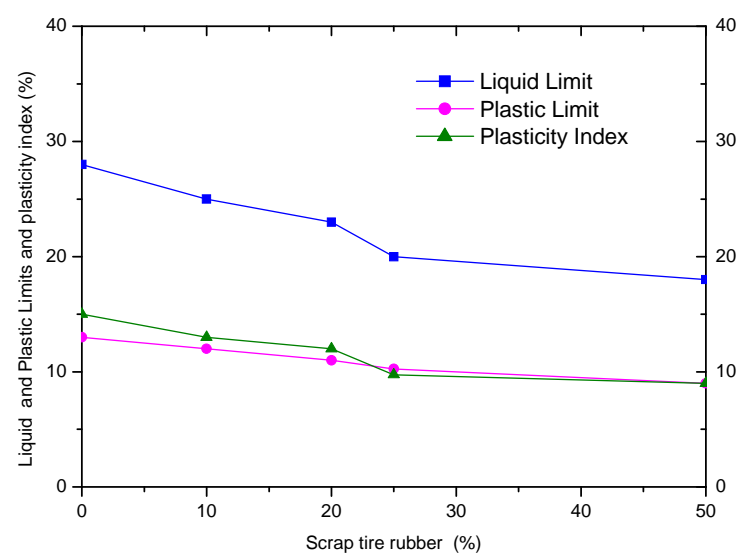

Fig. 3. Effect of rubber tires on the consistency limits of the soil T

Ab-Malek and Stevenson [34] studied the effect of 42 year immersion in sea water on natural rubber; they concluded that absorbed water of rubber has been less than $5 \%$ of its dry mass. The literature contains a considerable number of empirical techniques for assessing the swelling potential of soils, which correlated with consistency limits, moisture content, dry density, and depth of the soil samples [35].

\section{B. Direct Shear Tests (DST)}

Laboratory DSTs were conducted to measure the shear properties of a soil, including the yield point, the cohesion $\mathrm{C}$ and the soil internal friction angle $\varnothing$, as affected by different soil moisture contents and dry bulk densities. This test is carried out according to French standard [36]. Direct shear tests were conducted using an apparatus consisted of a soil shear box, a loading head, a weight hanger, and weights to generate 
normal loads. The shear box had two square rings for holding the soil sample. The cross-section of the box was 60 to $60 \mathrm{~mm}$ and the height was $50.8 \mathrm{~mm}$. The horizontal displacement of the movable ring was achieved with a motor. The tests are carried out in a damp and pressed state. The line of rupture is obtained following the application of three normal stresses $(1,2$ and 3 bar) to obtain more precision for the statistical study. Figure 4 and 5 show the curves of shearing tests. It is noted that there is a decrease in cohesion with the increase of scrap rubber. On the other hand, the line of variation of internal friction angle is almost vacillating depending on the scrap tire rubber content.

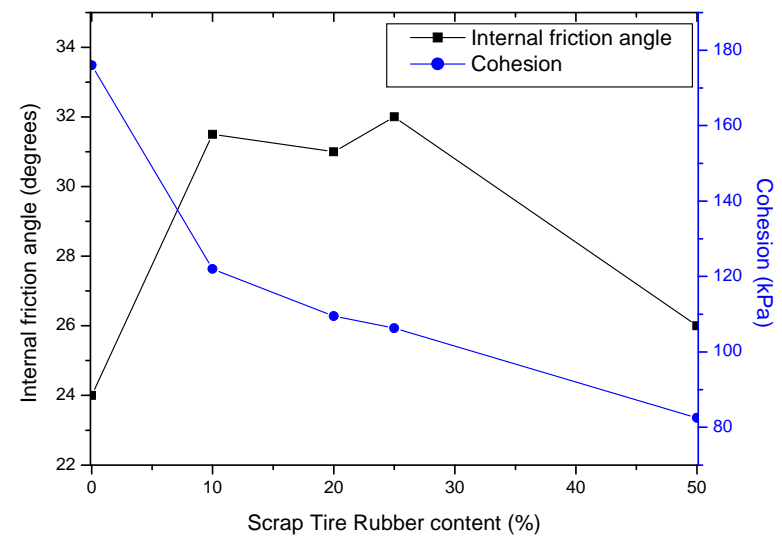

Fig. 4. Effect of rubber tires on cohesion and angle of internal friction of the soil S

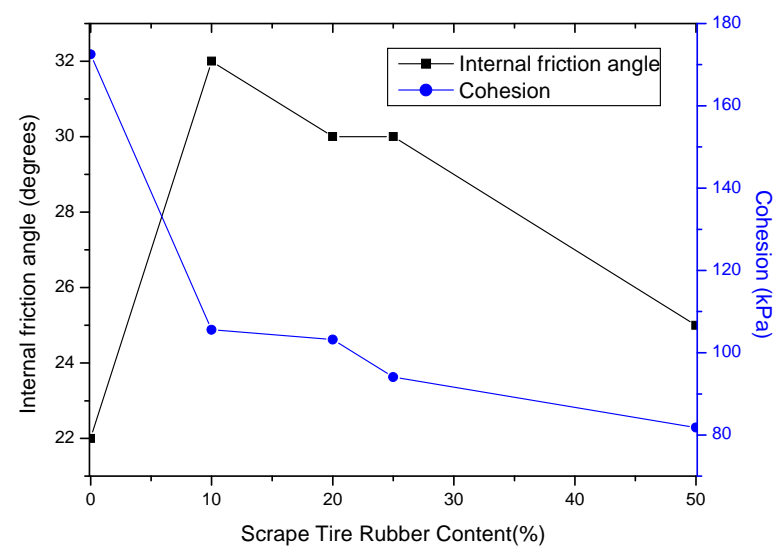

Fig. 5. Effect of rubber tires on cohesion and angle of internal friction of the soil $\mathrm{T}$

\section{Odometer tests : Loading-unloading tests}

Because tire rubber is highly compressible and its specific weight is less than half that of the soils, a complementary test program under odometer conditions was also performed to obtain additional information on the mechanical behaviour of the soils and the mixtures although the compressibility of rubber particles is considered negligible compared to the compressibility of the composite skeleton in computation. The compression index $C_{c}$ and the recompression index $C_{r}$ were determined for soils and composite samples according to [37].

\section{1) Effect of scrap tire rubber on Compression index.}

Figures 6 and 7 show the compression indices for the studied soils and mixtures. It is well known that the compression index $C_{c}$ is the slope of the linear portion of the pressure void ratio curve on a semi-log plot. The values of $C_{c}$ are relatively small because the remoulded $C_{c}$ is always smaller than the undisturbed $C_{c}$. The values vary from 0.126 to 0.423 for the Tizi Tuff and its mixtures and from 0.112 to 0.571 for Fergoug Sediment and its mixtures. For the two soils, $C_{c}$ increases gradually with rubber content.

\section{2) Effect of scrap tire rubber on recompression index}

The recompression (swell) index (i.e., slope of the $e-\log p$ plot during unloading or decompression) is presented in this study as the decompression index, $C_{r}$ (Figures 6 and 7). The values of the recompression index $C_{r}$ of undisturbed soil are generally about 5 times smaller than $C_{c}$ [38]. For all tested samples, $C_{r}$ is smaller than $C_{c}$ and it increases with scrap rubber content. The values of $C_{r}$ range from 0.114 to 0.261 for the Tizi Tuff and its mixtures and from 0.109 to 0.211 for Fergoug Sediment and its mixtures.

\section{Modified Proctor tests}

This test is carried out according to the French standard [39]. The optimal water content Wopt and the maximum dry density $G_{d \max }$ are determined. The Proctor curves are drawn taking into account the added scrap rubber. The results will be then compared with those obtained on Tizi Tuff. The values of optimum moisture content are $12.1 \%$ and $7.94 \%$ for respectively $\mathrm{S}$ and $\mathrm{T}$ soils, whereas the maximum dry density is about 1.97 for $\mathrm{T}$ soil which is $17 \%$ greater for $\mathrm{S}$ soil.

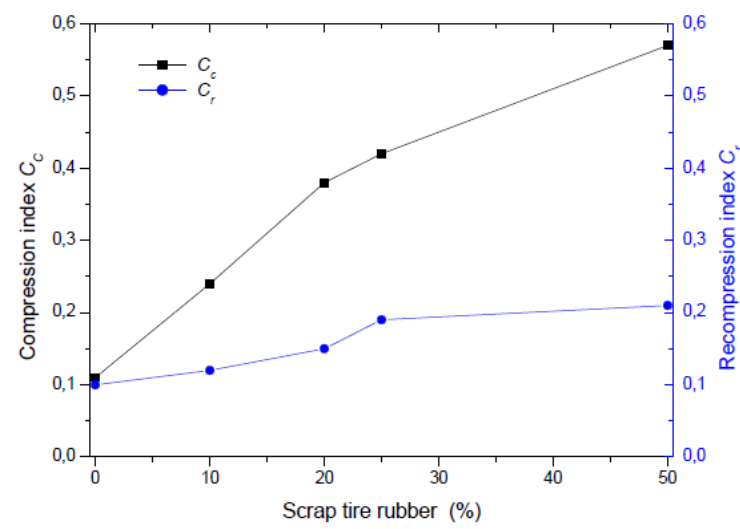

Fig. 6. Effect of tires rubber content on compression and recompression indices of soil S

With the addition of scrap tire rubber contents (Figure 8), the optimum moisture content and the maximum dry unit weights of $\mathrm{S}$ and $\mathrm{T}$ soils decrease. This can be due to change of the particle size distribution, organic content (especially for sediment) or surface area of the composite samples which can change the soil state from buoyant to semibuoyant. 


\section{E. CBR tests}

CBR (California Bearing Ratio) values are commonly used in mechanistic design as an indicator of strength and bearing capacity of a sub grade soil, sub base, and base course material used in road and airfield pavements. The CBR of a soil is the ratio obtained by dividing the stress required to cause a standard piston to penetrate $2.5 \mathrm{~mm}, 5.00 \mathrm{~mm}, 7.50 \mathrm{~mm}$ and $10.00 \mathrm{~mm}$ into the soil by a standard penetration stress at each depth of penetration [40]. The CBR may be thought of as an index value comparing the strength of the soil to that of crushed rock. CBR loading values according to different penetration for $\mathrm{S}$ and $\mathrm{T}$ soils and their mixtures for respectively $W=3$ and $5 \%$ are shown in Figures 9 and 10. CBR tests in this study were performed in accordance with [41]. CBR values for $\mathrm{S}$ and $\mathrm{T}$ soils and their mixtures are given in Table $\mathrm{V}$.

TABLE V. CBR VALUES OF SOILS AND MIXTURES.

\begin{tabular}{|c|c|c|}
\hline Soil mixtures & CBR values $(\boldsymbol{W}=\mathbf{3} \%)$ & CBR values $(\boldsymbol{W}=\mathbf{5 \%})$ \\
\hline $100 \% \mathrm{~S}$ & 16.56 & 11.54 \\
\hline $90 \% \mathrm{~S}+10 \% \mathrm{C}$ & 14.55 & 8.53 \\
\hline $80 \% \mathrm{~S}+20 \% \mathrm{C}$ & 7.53 & 4.52 \\
\hline $75 \% \mathrm{~S}+25 \% \mathrm{C}$ & 6.52 & 5.02 \\
\hline $50 \% \mathrm{~S}+50 \% \mathrm{C}$ & 4.01 & 3.01 \\
\hline $100 \% \mathrm{~T}$ & 15.55 & 12.04 \\
\hline $90 \% \mathrm{~T}+10 \% \mathrm{C}$ & 14.55 & 9.03 \\
\hline $80 \% \mathrm{~T}+20 \% \mathrm{C}$ & 8.03 & 8.03 \\
\hline $75 \% \mathrm{~T}+25 \% \mathrm{C}$ & 7.02 & 7.53 \\
\hline $50 \% \mathrm{~T}+50 \% \mathrm{C}$ & 4.52 & 2.51 \\
\hline
\end{tabular}

Results indicate that CBR values for the two soils decrease with scrap tire rubber content. The maximal value of CBR is given for $W=3 \%$ for all mixtures except for the mixture of $\mathrm{T}$ soil with $25 \%$ of scrap tire rubber where the maximal CBR value was obtained for $W=5 \%$. The Fergoug sediment needs greater pressure to make power for the penetration than the Tizi Tuff. Thus, the pressure of $3 \%$ is more than the pressure of $5 \%$, which proves that water impacts negatively on the compaction characteristics of mixtures. Also the scrap rubber affects negatively on CBR values of soils. The results highlight an appreciable increase in load compaction when the additions of $20 \%$ of scrap tire rubber are proceeded.

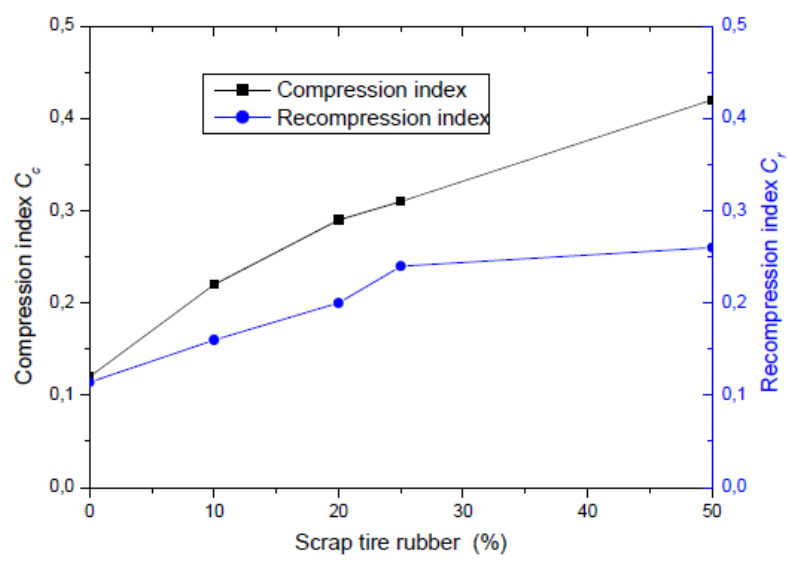

Fig. 7. Effect of tires rubber content on compression and recompression indices of soil $\mathrm{T}$

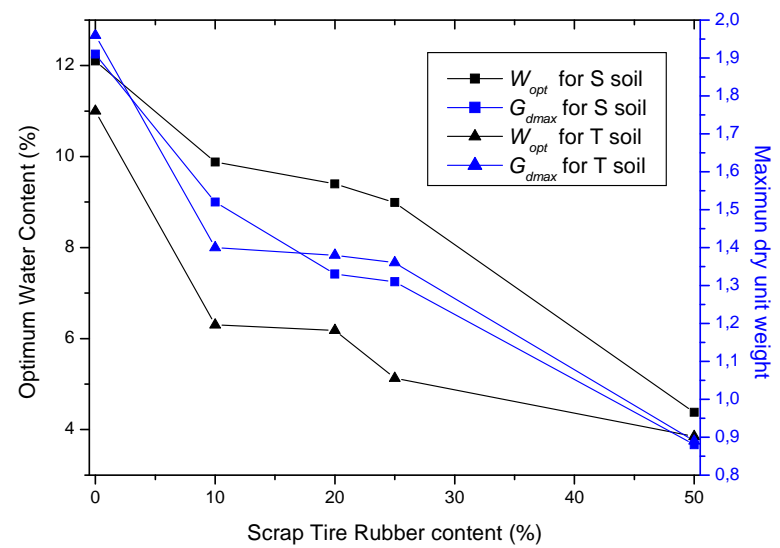

Fig. 8. Evolution of Features Proctor for S and T soils and theirs mixtures.

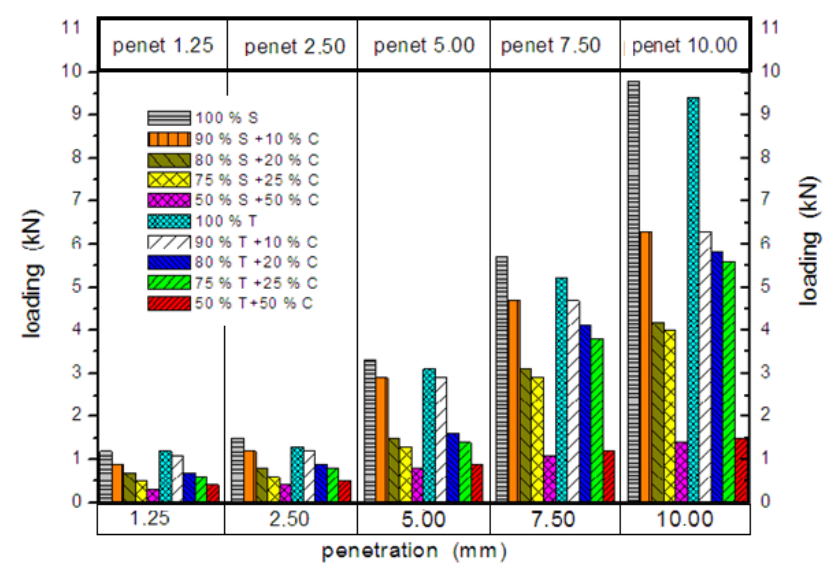

Fig. 9. CBR loading according to different penetration for $\mathrm{S}$ and $\mathrm{T}$ soils and their mixtures for $W=3 \%$.

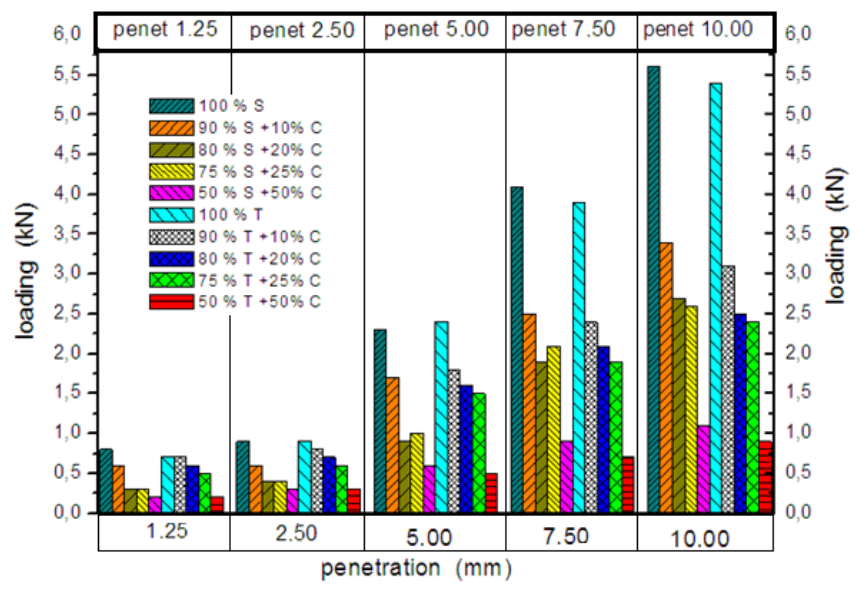

Fig. 10. CBR loading according to different penetration for S and T soils and their mixtures for $W=5 \%$. 


\section{CONCLUSION}

In this study, the effect of scrap rubber content on the geotechnical characteristics of Fergoug sediment and Tizi Tuff were investigated and the following conclusions were drawn:

- Geotechnical's characteristics vary depending on the scrap rubber content: the liquid limit, the plasticity index rundown with the increase of scrap tire rubber content. This decrease is more significant for plastic soil.

- The scrap tire rubber content changed the compaction parameters of Fergoug sediment and Tizi Tuff. The optimum moisture content and specific weight values decreased with the scrap tire rubber contents.

- For shearing tests, a decrease in cohesion with the increase of scrap tire rubber is observed when the variation of internal friction angle is vacillating.

- Compression and recompression indexes increase gradually with the scrap tire rubber content for the two soils. The increase is more significant for the compression index.

- The CBR values for $W=3 \%$ are larger than those for $W=5 \%$ except for the mixture (75\% Tuff $+25 \%$ Scrap tire rubber). Thus, the pressure needed for a water content $W=3 \%$ is greater than for $W=5 \%$. This proves that water impacts negatively on the proctor soil.

\section{REFERENCES}

[1] World Commission on Dams, Dams and development: a new framework for decision-making, Earth Scan Publications Ltd, London, 2000

[2] J. de Vente, J. Poesen, G. Verstraeten, "The application of semiquantitative methods and reservoir sedimentation rates for the prediction of basin sediment yield in Spain”, Journal of Hydrology, Vol. 305, No. 1-4, pp. 63-86, 2005

[3] Z. Labiod, H. Trouzine, M. S. Ghembaza, T. Nouioua, Y. Sebaibi, "Experimental investigation of mixtures of bentonite and dredged sediments from Chorfa dam in Algeria”, Turkish Journal of Earth Sciences, Vol. 23, pp. 330-338, 2014

[4] A. Semcha, "Valorisation des sédiments de dragage : Applications dans le BTP, cas du barrage de Fergoug", Thèse 175p . Université de Reims Champagne-Ardenne, France, 2006 (In French)

[5] V. Fonti, A. Dell' Anno, F. Beolchini, “Influence of biogeochemical interactions on metal bioleaching performance in contaminated marine sediment”, Water Research , Vol. 47, No. 14, pp. 5139-5152, 2013

[6] A. J. Koiter, P. N. Owens, E. L. Petticrew, D. A. Lobb, "The behavioural characteristics of sediment properties and their implications for sediment fingerprinting as an approach for identifying sediment sources in river basins”, Journal of Earth-Science Reviews, Vol. 125, pp. 24-42, 2013

[7] M. Diaz-Jaramillo, A. Martins Da Rocha, G Chiang, D. Buchwalter, J. M. Monserrat, R. Barra, "Biochemical and behavioral responses in the estuarine polychaete Perinereis gualpensis (Nereididae) after in situ exposure to polluted sediments", Ecotoxicology and Environmental Safety, Vol. 89, pp. 182-188, 2013

[8] C. Y. Chen, C. J. Tien, Y. M. Sun, C. Y. Hsieh, C. C. Lee, "Influence of water quality parameters on occurrence of polybrominated diphenyl ether in sediment and sediment to biota accumulation”, Chemosphere, Vol. 90, pp. 2420-2427, 2013

[9] M. Kumar, H. Furumai, F. Kurisu, I. Kasuga, "Tracing source and distribution of heavy metals in road dust, soil and soakaway sediment through speciation and isotopic fingerprinting”, Geoderma, Vol. 211212, pp. 8-17, 2013
[10] M. Miraoui, R. Zentar, N. E. Abriak, "Road material basis in dredged sediment and basic oxygen furnace steel slag", Construction and Building Materials, Vol. 30, pp. 309-319, 2013

[11] A. Sabbatini, S. Bonatto, S. Bianchelli, A. Pusceddu, R. Danovaro, A. Negri, "Foraminiferal assemblages and trophic state in coastal sediments of the Adriatic Sea”, Journal of Marine Systems, Vol. 105-108, pp. 163174, 2012

[12] H. Zhao, X. Li, "Understanding the relationship between heavy metals in road-deposited sediments and washoff particles in urban stormwate using simulated rainfall”, Journal of Hazardous Materials, Vol. 246-247, pp. 267-276, 2013

[13] A. R. Wijaya, A. K. Ouchi, K. Tanaka, R. Shinjo, S. Ohde, "Metal contents and $\mathrm{Pb}$ isotopes in road-side dust and sediment of Japan", Journal of Geochemical Exploration, Vol. 118, pp. 68-76, 2012

[14] H. Trouzine, A. Asroun, N. Asroun, F. Belabdelouhab, N. T. Long, "Problématique des pneumatiques usagés en Algérie", Nature \& Technologie, Vol. 5, pp. 28-35, 2011 (in French)

[15] K. A. Venkataraman, K. Kanthavel, B. Nirmal Kumar, "Investigations of response time parameters of a pneumatic $3 / 2$ direct acting solenoid valve under various working pressure conditions”, Engineering, Technology \& Applied Science Research, Vol. 3, No. 4, pp. 502-505, 2013

[16] H. Trouzine, M. Bekhiti, A. Asroun, "Effects of scrap tire rubber fibre on swelling behaviour of two clayey soils in Algeria”, Geosynthetics International, Vol. 19, No. 2, pp. 124-132, 2012

[17] NF P 94-051, Sols: Reconnaissance et Essais - Détermination des limites d'Atterberg - Limite de liquidité à la coupelle - limite de plasticité au rouleau. Association Française de Normalisation, France (in French)

[18] NF P 94-054, Sols: reconnaissances et essais, Détermination de la masse volumique des particules solides des sols, Méthode du pycnomètre à eau. Association Française de Normalisation, France (in French)

[19] NF P 94-056, Sols: reconnaissances et essais, Analyse granulométrique, Méthode de tamisage à sec après lavage. Association Française de Normalisation, France (in French)

[20] NF P 94-057, Sols: reconnaissances et essais, Analyse granulométrique des sols, Méthode par sédimentation. Association Française de Normalisation, France. (in French)

[21] NF P 94-068, Sols : Reconnaissance et essais, Mesure de la capacité d'adsorption de bleu de méthylène d'un sol ou d'un matériau rocheux, Détermination de la valeur de bleu de méthylène d'un sol ou d'un matériau rocheux par l'essai à la tache. Association Française de Normalisation, France (in French)

[22] NF EN 1744, Essais visant à déterminer les propriétés chimiques des granulats. Association Française de Normalisation, France (in French)

[23] State of California Department of Transportation, Asphalt rubber usage guide, Sacramento, California, USA, 2006

[24] L. A. Alamo-Nole, O. Perales-Perez, F. R. Roman-Velazquez, "Sorption study of toluene and xylene in aqueous solutions by recycled tires crumb rubber”, Journal of Hazardous Materials, Vol. 185, No.1, pp. 107-111, 2011

[25] T. Amari, N. Themelis, I. Wernick, "Resource Recovery from used rubber tires”, Resources Policy, Vol. 25, No. 3, pp. 179-188, 1999

[26] T. L. Nguyen, The pneusol research-projects-prospects, PhD thesis, The National Institute of Applied Sciences in Lyon France 1993

[27] Y. Cai, B. Shi, C. Ng, C. Tang, "Effect of polypropylene fibre and lime admixture on engineering properties of clayey soil", Engineering Geology, Vol. 87, No. 3-4, pp. 230-240, 2006

[28] S. Akbulut, S. Arasan, E. Kalkan, "Modification of clayey soils using scrap tire rubber and synthetic fibers", Applied Clay Science, Vol. 38, No. 1-2, pp. 23-32, 2007

[29] H. Cetin, M. Fener, O. Gunaydin, "Geotechnical properties of tirecohesive clayey soil mixtures as a fill material”, Engineering Geology, Vol. 88, No. 1-2, pp. 110-120, 2006

[30] F. G. Bell, Engineering treatment of soils, E \& FN Spon, Chapman and Hall, Boundary Row, London, UK, pp302, 1993 
[31] C. O. Okagbue, T. U. S. Onyeobi, "Potential of marble dust to stabilise red tropical soils for road construction", Journal of Engineering Geology, Vol. 53, No. 3-4, pp. 371-380, 1999

[32] P. V. Sivapullaiah, A. Sridharan, K. V. Bhaskar Raju, "Role of amount and type of clay in the lime stabilization of soils", Proceedings of the ICE - Ground Improvement, Vol. 4, No. 1, pp. 37-45, 2000

[33] R. M. Schmitz, C. Schroeder, R. Charlier, "Chemo-mechanical interactions in clay a correlation between clay mineralogy and Atterberg limits”, Applied Clay Science, Vol. 26, No. 1-4, pp. 351-358, 2004

[34] K. Ab-Malek, A. Stevenson, "The effect of 42 year immersion in seawater on natural rubber”, Journal of Materials Science, Vol. 21, No. 1, pp. 147-154, 1986

[35] H. B. Seed, R. J. J. Woodward, R. Lundgren, "Prediction of swelling potential for compacted clays", Journal of Soil Mechanics and Foundation, ASCE, Vol. 88, No. SM-3(Part 1), pp. 53-87, 1962

[36] NF P 94-071-1, Sols: reconnaissance et essai-Essai de cisaillement rectiligne à la boite: cisaillement direct. Association Française de Normalisation, France (in French)

[37] XP P 94-091, Sols: reconnaissances et essais, Essai de gonflement à l'odomètre. Détermination des déformations par chargement de plusieurs éprouvettes. Association Française de Normalisation, France. (in French)
[38] XP P 94-090-1, Sols: reconnaissances et essais, Essai œdométrique, Partie 1: Essai de compressibilité sur matériaux fins quasi saturés avec chargement par paliers. Association Française de Normalisation, France. (in French)

[39] NF P 94-093, Sols : Sols: reconnaissance et essai - Détermination des caractéristiques de compactage d'un sol : essai Proctor normal, essai Proctor modifié.. Association Française de Normalisation, France. (in French)

[40] NF P 94-078. Soils: investigation and tests. CBR after immersion. Immediate CBR. Immediate bearing ratio. Measurement on sample compacted in CBR mould, May 1997 (in French)

[41] K. Hazirbaba, H. Gullu, "California Bearing Ratio improvement and freeze-thaw performance of fine-grained soils treated with geofiber and synthetic fluid”, Cold Regions Science and Technology, Vol. 63, No. 12, pp. 50-60, 2010

[42] B. Yildirima, O. Gunaydin, "Estimation of California bearing ratio by using soft computing systems”, Expert Systems with Applications, Vol. 38, pp. 6381-6391, 2011 